\title{
Effect of Credit Risk on Shareholders' Wealth of Listed Commercial Banks in Kenya
}

\author{
Kinyamasyo Abigail Kathini, BSc \\ Opuodho Gordon Ochere, PhD
}

Department of Economics, Accounts and Finance

Jomo Kenyatta University of Agriculture and Technology, Kenya

\section{Doi:10.19044/esj.2020.v16n22p205 URL:http://dx.doi.org/10.19044/esj.2020.v16n22p205}

\begin{abstract}
The financial manager's mandate is to maximize shareholders' wealth by investing in projects with positive cash flows. Credit risk is the potential loss incurred by a company when counterparties default in their financial obligations. This leads to cash out flow, which in turn affects shareholders' wealth. To achieve higher returns, financial managers must take more risk. This paper focuses on determining the effect of credit risk on shareholders' wealth of listed commercial banks in Kenya. Secondary data was collected from the annual financial statements of 11 listed commercial banks and the corporation credit ratings publications for the period 2014 to 2018. Through quantitative research design, panel data was analyzed using multiple linear regression model. The study found that capital adequacy had a significant positive effect on shareholders wealth. Non-performing loans, credit liquidity, loan loss provision, and credit ratings had an insignificant effect on shareholders wealth. Based on F statistic results, credit risk had a significant negative effect on shareholders wealth. The study recommends that financial managers should retain more capital based on the risk weighted assets which acts as a buffer if the bank incurs losses arising from credit risk. Commercial banks in Kenya should also fully adopt the Basel III Accord requirements so as to maximize the wealth of the shareholders.
\end{abstract}

Keywords: Credit risk, Shareholders wealth, Capital Adequacy, Nonperforming loans, Credit liquidity

\section{Introduction}

The banking industry is the leading sector which offers financial services in most countries globally. As a result, banks face a wide range of financial risks which include market risk, operational risk, and credit risk (Rasika, Dgl \& Sampath, 2016). They generate income mainly by lending 
funds in the form of loans and mortgages, and this makes credit risk the most susceptible risk that most Kenyan banks face (Isanzu, 2017). Credit risk is the potential loss that a bank incurs if the borrower or a counter party fails to honor his or her obligation per the agreed terms (The Basel Committee, 2016). Credit risk is the loss arising from unpaid principal and interest emanating from failure of a loan borrower to repay his or her loan, which results in failure to meet the contractual agreement (Perera \& Morawakage, 2017).

Kenya's central bank has come up with reforms to reduce the financial risks that banks face. The regulatory body has further implemented Basel Accord requirements for risk management. According to the prudential guidelines for commercial banks in Kenya, banks ought to maintain a minimum core capital requirement of Ksh. I billion based on the risk weighted assets. In addition, banks should further classify their loans as normal, watch, sub-standard, doubtful, and as loss loans whereby sub-standard, doubtful, and loss loans are classified as non-performing loans. The banks should also maintain a provision of $20 \%$ of the substandard loans, $100 \%$ of doubtful loans, and $100 \%$ of loss loans as a risk management strategy (Central Bank of Kenya, 2013). Basel I Accord requires banks to maintain a minimum capital requirement of $8 \%$ on the risk weighted assets as a reserve (The Basel Committee, 2006). Basel Accord III emphasizes on liquidity where the minimum capital requirement regulation is key and also introduces a capital conservation reserve.

Shareholders are the capital providers, residual claimants, and risk bearers of an organization (Chary \& Mohanty, 2009). They expect managers to maximize their capital by investing in projects with positive cash inflows (Ahmad \& Hussanie, 2018). Nonetheless, they also have to bear a higher risk in order to enjoy high returns. However, over the years, banks in Kenya have been collapsing due to losses arising from credit risk. For instance, Imperial Bank collapsed in 2016 due to bad loans and Dubai Bank collapsed in 2015 due to capital deficiencies and illiquidity (Gathaiya, 2017). In addition, nonperforming loan to gross loans ratio of banks in Kenya has also increased over the years from 8.8 in 2008 to 11.66 in 2016 and 10.6 in 2018, which presents high default rates (World Bank, 2019).

\section{Literature Review}

Literature review analyses the opinions of other scholars who have performed their work on credit risk and shareholders wealth for commercial banks across the globe. This study was guided by two theories, namely agency theory and asymmetric information theory. 


\subsection{Agency Theory}

Agency theory is a finance theory that was proposed by Ross (1973) who stated that the key problem in an agency relationship arises from incentive or compensation system. Ross outlined the key variables of the problem to be the risk condition and the information condition. If the agent and the principal are utility maximizers, there is a high potential that the agent will not always act in good faith and with the best interest of the principal. Jensen and Meckling (1976) stated that agency cost involves the expenditure incurred by the principal to monitor the agent's activities. Porter and Palia (2018) examined agency theory in the banking sector and concluded that agent compensation incentive is positively related to risk. The high risk uptake by the agent is what led to financial crisis in 2007 (Donnellan, 2016). The shareholders expect that managers will maximize their wealth by making prudent choices in relevance to the total capital they issue in form of loans and the capital they retain as a buffer.

\subsection{Asymmetric Information Theory}

Asymmetric information theory was proposed by Akerlof (1970) who stated that due to different interpretation of quality and uncertainty, markets are faced with problems. The study illustrated the problem through the use of good and bad cars. Here, bad cars were referred to as 'melons'. It would be difficult for a buyer to distinguish between a good car and a melon. Therefore, most sellers take advantage of this and sell melons. Spence (2006) expanded on this idea and highlighted that, in an investment under uncertainty, it is important that the investor studies the signals. It was concluded that the study of signals relies on the previous experience in the market, and the principle could be applied in admission procedures, organizational promotion, and loans. Asymmetry of information leads to moral hazard and adverse selection (Chantal, Namusonge \& Shukla, 2018). If borrowers' past information is not well gathered, it may lead to increased non-performing loans. This, in turn, leads to increased credit risk and bank failure (Nyoni, 2018).

\subsection{Empirical Review}

Capital adequacy is a bank supervisory requirement outlined in Basel Accords that requires banks to hold some reserve based on bank assets that have been weighted on risk. Also, it is used as a buffer in times of financial distress. Stovrag (2017) evaluated the effect of capital requirements on bank profitability and compared the effect between the large and niche Swedish banks for the year 1999 to 2015 . The study used a mixed model approach for both quantitative and qualitative statistical techniques and concluded that capital requirements and profitability were significantly negatively correlated. 
They also pinpointed that factors such as a bank's capital structure and its size could have an effect on the minimum capital.

Feyzi, Ghorbanian, and Berangi (2016) conducted a research on credit risk indicators and the extent to which they affect shareholders' worth of the listed commercial banks in Tehran Stock Exchange in Iran for the period 2005 to 2010. Using a multiple linear regression model, they concluded that capital adequacy and shareholders' value measured by ROE were negatively correlated. They further argued that capital adequacy is an important indicator since it is one of the requirements outline by Basel commission.

A loan is termed to be a non-performing loan if the borrower has not honored his/her principal and interest obligation in 90 days or even more. Muriithi, Munyua, and Muturi (2016) studied the effect of credit risk on financial performance for the Kenyan commercial banks for the period 2005 to 2014. Panel data and generalized method of moments were used to measure the effect. They concluded that the most significant variable was the nonperforming loan ratio which had a significant negative effect on financial performance, while loan loss provision had a significant positive effect on financial performance. Therefore, managers should intensify their credit analysis together with employing the most effective credit policies to minimize the non-performing loans.

Perera and Morawakage (2017) also studied Credit Risk Management and Shareholder Value Creation for listed commercial banks in Sri Lankan. Regression analysis was used to model the secondary data and they found out that non-performing loans had the most significant effect on shareholders' worth measured by return on shares. If the non-performing loans increase, the profit of the banks decreases and the value of the shareholders decreases also.

Credit liquidity has had inconsistent empirical findings on its effect on shareholders wealth. Bwacha and Xi (2018) studied the impact of liquidity on the profitability of banks from 2008 to 2017. In addition, the impact was studied as an aftermath of 2007/2008 financial crisis. Furthermore, the ratios were regressed in a multiple linear regression model, which showed that total loans and advances to customer deposit ratio had an insignificant effect on Banks Profitability.

Funso et al. (2012) conducted a study on credit risk and commercial banks performance in Nigeria using a sample of five banks selected from a population of eleven banks for the period 2000 to 2010. Panel data and multivariate analysis were used to verify the associations among the variables. Non-performing loans and loan loss provision had a negative effect on financial performance. On the other hand, total loan and advances portrayed a positive effect on financial performance of the banks. They concluded that loans and advances ratio exerts the most significant positive relationship. 
In addition, loan loss provision had inconsistent findings. Luqman (2014) carried out a study on credit risk and its effect on financial performance. The study used a sample of five commercial banks in Nigeria for the period 2008 to 2012. Using secondary data, total loans and advances to deposits ratio had an insignificant negative effect on financial performance measured by return on assets. They therefore concluded that there was no significant relationship between credit liquidity and performance of commercial banks in Nigeria.

Bebeji et al. (2014) examined the impact of loan loss provision on banks' credit in the Federal Republic of Nigeria from the year 2002 to 2008. The study used secondary data obtained from the annual reports of 10 sampled commercial banks. They found out that loan loss provision had a negative effect on Nigerian banks credit. The study recommended that banks should support a strict requirement of the quantity of loan loss provision set.

Credit ratings are ratings released by credit rating companies which explain the credit worthiness of a firm. Zhao, Moreira, Wang, and Wang (2018) carried out a study of sovereign and bank rating effect on financial performance of commercial banks in Europe, and it was established that ratings are usually used to externally communicate the riskiness of a firm. Also, they can alter the investors' confidence about the bank's performance. They therefore concluded that credit ratings, either sovereign or bank rating, had a negative effect on financial performance of banks.

\section{Methodology}

To determine the effect of credit risk on shareholder wealth, the study employed quantitative research design. The study's target population focused on licensed commercial banks in Kenya. Using purposive sampling, the study sampled 11 listed commercial banks as of 2018 due to availability of data. Secondary panel data was collected from the reported financial statements of respective banks and from the credit rating publications for the period 2014 to 2018. The data were then analyzed by employing multiple linear regression to assess the effect of credit risk on shareholders' wealth. Measures of central tendency, dispersion, and position were used to statistically describe the data. Diagnostic test were used to check whether the data met the ordinary least square assumptions. They included multicollinearity, homoscedasticity, and serial correlation test. Tobin's q was the measure of shareholders' wealth while credit risk had five measures namely non-performing loan ratio (NPLR), capital adequacy ratio (CAR), credit liquidity ratio (CLR), loan loss provision ratio (LLPR), and credit rating scores (CRS). The model of this study is as follows:

$$
\text { Tobin's } q=\mathrm{f}(N P L R, C A R, C L R, L L P R, C R S)
$$

Upon linearization and parametrization, the regression equation became: 


$$
\begin{aligned}
\text { Tobin's } q_{i, t}= & B_{0}+B_{1} N P L R_{i, t}+B_{2} C A R_{i, t}+B_{3} C L R_{i, t}+B_{4} L L P R_{i, t} \\
& +B_{5} C R S_{i, t}+\varepsilon_{i, t}
\end{aligned}
$$

Where:

Tobin's q $=($ Market value of equity + Book value of debt $) /$ Total assets

NPLR $=$ Non-performing loan/Total loans

$\mathrm{CAR}=($ Tier $1+$ Tier 2$) /$ Credit risk weighted assets

CLR $=$ Total Loans and advances/Total deposit

LLPR $=$ Loan loss provision/classified loans

CRS $=$ Credit rating score ${ }_{\mathrm{t}}-$ Credit rating score $\mathrm{t}-1$

$\varepsilon=$ Error term

\section{Data Analysis and Discussions}

Table 1. Descriptive Statistics

\begin{tabular}{crrrrrr}
\hline & \multicolumn{1}{c}{ NPLR } & \multicolumn{1}{c}{ CAR } & \multicolumn{1}{c}{ CLR } & LLPR & CRS & Tobin's Q \\
\hline Size & 55 & 55 & 55 & 55 & 55 & 55 \\
Mean & 0.1259527 & 0.1798855 & 0.8392055 & 0.460591 & -0.05455 & 0.273616 \\
Standard deviation & 0.2643452 & 0.03652 & 0.1953874 & 0.160251 & 0.29927 & 0.107538 \\
Skewness & 5.993866 & -2.15513 & 0.8384409 & 0.717614 & -1.49213 & 0.933897 \\
Excess Kurtosis & 37.90879 & 5.523871 & 1.106644 & 0.891679 & 7.048684 & 1.909838 \\
Minimum & 0.0114 & 0.0369 & 0.454 & 0.1427 & -1 & 0.0681 \\
Maximum & 0.9453 & 0.2277 & 1.4072 & 1 & 1 & 0.6792 \\
\hline
\end{tabular}

As seen in Table 1, the mean of NPLR showed that, across the banks and over the years, the NPLR was concentrated at 0.12595 with individual ratios varying from the mean with a percentage of 26.435. The mean of the CAR revealed that banks averagely maintained a capital buffer of $17.989 \%$ of the risky weighted assets over the years with the capital reserved varying from the mean by \pm 0.03652 . Banks further retained a provision of $46.06 \%$ of the classified loans and were unable to fully maximize the shareholders wealth. This means that, on average, the banks created a wealth of 0.2736 which was less than 1. Based on the above skewness results, extreme values of NPLR, CLR, LLPR, and the Tobin's Q ratios were on the right side of the normal distribution tail, while those of CAR and CRS were on the left side of the normal distribution tail. In addition, based on excess kurtosis results, NPLR, CRS, CAR, Tobin's Q ratio, and CLR followed a leptokurtic distribution characterized by extreme values on either side. Consequently, LLPR followed a mesokurtic distribution which indicates that its distribution was almost the same as that of a normal distribution.

\section{Diagnostic Tests}

Diagnostics test were conducted on the data to examine if it fulfilled the linear regression assumption before determining the influence of credit risk 
on shareholders wealth. The diagnostic test conducted on the data included homoscedasticity, serial correlation, and multicollinearity.

Table 2. Multicollinearity Test

\begin{tabular}{crrrrr}
\hline & CAR & CLR & LLPR & NPLR & CRS \\
\hline CAR & 1.0000000 & 0.2831588 & -0.0449931 & -0.7129112 & -0.0929262 \\
CLR & 0.2831588 & 1.0000000 & -0.0248151 & -0.3255690 & 0.0240426 \\
LLPR & -0.0449931 & -0.0248151 & 1.0000000 & -0.0457158 & 0.0946320 \\
NPLR & -0.7129112 & -0.3255690 & -0.0457158 & 1.0000000 & 0.0209173 \\
CRS & -0.0929262 & 0.0240426 & 0.0946320 & 0.0209173 & 1.0000000 \\
\hline
\end{tabular}

Using covariance matrix as a test for multicollinearity, independent variables are said to have multicollinearity effect if the variables have very high correlations (Daoud, 2018). CLR, LLPR, and CRS had low correlation among themselves as well as with NPLR and CAR ratio. The NPLR had a relatively strong negative correlation with the capital adequacy ratio. However, since the correlation was slightly above 0.7 , the study found that there was no multicollinearity in the data.

Table 3. Homoscedasticity Test

\begin{tabular}{cc}
\hline \multicolumn{2}{c}{ Studentized Breusch-Pagan test } \\
\hline Data & Pooling panel data \\
BP & 2.3766 \\
df & 4 \\
p-value & 0.6669 \\
\hline
\end{tabular}

Homoscedasticity test was done using Studentized Breusch-Pagan test with a null hypothesis of no heteroskedasticity. In Table 3 , the p-value of 0.6669 is greater than 0.05 . Therefore, the study failed to reject null hypothesis and concluded that the error term variance was constant.

Table 4. Serial Correlation Test

\begin{tabular}{cc}
\hline \multicolumn{2}{c}{ Breusch-Godfrey/Wooldridge test for serial correlation in panel models } \\
\hline Data & Tobin.s.Q $\sim$ NPLR + CAR + CLR + LLPR + CRS \\
Chisq & 9.2451 \\
Df & 5 \\
p-value & 0.09968 \\
& Alternative hypothesis: serial correlation in idiosyncratic errors \\
\hline
\end{tabular}

The study employed Breusch-Godfrey/Wooldridge test for serial correlation with the null hypothesis of no serial correlation in idiosyncratic errors. Table 4 shows the p-value of $0.09968>0.05$. Therefore, the study failed to reject the null hypothesis and concluded that there was no serial correlation. 


\section{Regression Analysis}

The study employed panel data also known as pooled data, which is a combination of time series data and cross-sectional data (Gujarati, 2013). Credit risk is the potential loss a lender may incur if the borrower reverts was measured using five credit drivers, namely non-performing loans, capital adequacy, credit liquidity, loan loss provision, and credit ratings (Central bank of Kenya, 2013). To determine its overall effect on shareholders wealth, a pooled model of regression analysis for panel data was fitted and the following results, as shown in Table 6 , were obtained.

Table 6. Regression Output

Pooling Model

Balanced Panel: $\mathrm{n}=11, \mathrm{~T}=5, \mathrm{~N}=55$

Residuals:

Min

$-0.128973$

1st Qu.

$-0.0773$

Median 3rd Qu.

Max

$-0.011609 \quad 0.061337$

0.360219

Coefficients:

\begin{tabular}{|c|c|c|}
\hline & Estimate & Std. Error \\
\hline (Intercept) & -0.0263856 & 0.1231149 \\
\hline NPLR & -0.0097885 & 0.0717367 \\
\hline CAR & 1.2011564 & 0.5114887 \\
\hline CLR & 0.1095311 & 0.0705311 \\
\hline LLPR & -0.0146656 & 0.0816562 \\
\hline CRS & 0.053283 & 0.043653 \\
\hline \multicolumn{3}{|c|}{ Signif. codes: 0 ‘*** 0.001 '**’ 0.01 '*’ 0.05 ' 0.1 ‘ } \\
\hline \multicolumn{3}{|c|}{ Total Sum of Squares: $\quad 0.62448$} \\
\hline \multicolumn{2}{|c|}{ Residual Sum of Squares: } & \\
\hline \multicolumn{2}{|c|}{ Multiple R-squared: } & \\
\hline \multicolumn{2}{|c|}{ Adjusted R-squared: } & \\
\hline
\end{tabular}

NPLR had a negative effect on Tobin's q such that a unit increase in NPLR leads to a 0.0097885 decrease in Tobin's q ratio. This was consistent with the findings of Muriithi et al. (2016) and Perera and Morawakage (2017). They found out that non-performing loans had a negative effect on financial performance and shareholders value respectively. However, since the $p$ value was greater than 0.05 , the study concluded that non-performing loans did not have a significant negative effect on shareholders wealth. Also, LLPR had a negative effect on Tobin's q such that a unit increase in LLPR leads to a 0.0146656 decrease in Tobin's q ratio. The results were consistent with the findings of Bebeji et al. (2014) and Million et al. (2016) who concluded that LLPR had a negative effect on Nigerian bank profitability and financial 
performance respectively. Since the $\mathrm{p}$ value was greater than 0.05 , the study concluded that LLPR did not have a significant effect on shareholders wealth.

CLR and CRS also had a positive effect of 0.1095311 and 0.053283 on Tobin's q. Since the p values of 0.12674 and 0.22808 were greater than 0.05 , the study concluded that their effect on shareholders wealth was insignificant. This was consistent with the findings of Funso et al. (2012) which showed that credit liquidity had a positive effect on the profitability of commercial banks in Nigeria. On the other hand, the findings of Bwacha and $\mathrm{Xi}$ (2018) and Luqman (2014), revealed that CLR had a positive effect on financial performance. Furthermore, the findings of Zhao et al. (2018) showed that credit ratings had a negative effect on financial performance. The general model of regression used to forecast credit risk effect on shareholders wealth was given as:

$$
\begin{aligned}
\text { Tobin's } q= & -0.0263856-0.0097885 N P L R+1.2011564 C A R \\
& +0.1095311 \text { CLR }-0.0146656 L L P R+0.053283 C R S+\varepsilon
\end{aligned}
$$

The most important credit risk driver that affected the shareholders wealth was CAR, since it was the only significant variable with a $p$ value of 0.02285 which was less than 0.05. Thus, a unit increase in CAR leads to a 1.2011564 increase in shareholders wealth. This was, however, inconsistent with the findings of Stovrag (2017) and Feyzi et al. (2016) which revealed that capital adequacy had a negative impact on a bank's profitability. F test was used to collectively examine if the five credit risk drivers had negative effect on shareholders wealth. Since the F statistic p value of 0.0028667 was less than 0.05 , the study concluded that the data was well fitted in the regression model and credit risk had a significant negative effect on shareholders wealth. The findings of this study were consistent with the existing literature findings of Muriithi et al. (2016) and Isaac et al. (2017) which showed that credit risk had a negative effect on financial performance and stock returns for commercial banks in Kenya.

\section{Summary, Conclusion, and Recommendations}

The study aimed to evaluate the effect of credit risk on the wealth of shareholders for commercial banks in Kenya where non-performing loans, capital adequacy, credit liquidity, credit ratings, and loan loss provision were the credit risk drivers and Tobin's q was the measure of shareholders wealth. Credit risk only explained $27.11 \%$ change in shareholders wealth and had a negative significant effect on shareholders wealth. Non-performing loans and loan loss provision had an insignificant negative effect on shareholders wealth, while credit liquidity and credit ratings had an insignificant positive effect on shareholders wealth. The study concluded that the most significant variable which affected shareholders wealth was capital adequacy. Thus, banks should issue more loans since the higher the risk the higher the return. However, more 
capital needs to be reserved to protect the shareholders in the event of default in order to maximize the shareholders wealth.

This explains the reason why the capital adequacy has been an important requirement for banks across the globe. Based on the previous bank crises, the Basel committee drafted the capital requirement in their first committee. This has been developed further in the proceeding Basel II and III Accords. Therefore, the study recommends that bank managers should fully adopt the Basel III requirement for banks by holding capital conservation reserve that protects the shareholders in times of financial distress in order to maximize the shareholders wealth. A further research can be conducted in all financial institutions in Kenya while taking into account the potential loss that they incur if a counter party in a derivatives contract (futures contract) defaults in their obligations.

\section{References:}

1. Ahmad, Z. \& Hussanie, I. (2018). Shareholders Wealth Maximization: Objective of Financial Management Revisited. International Journal of Enhanced Research in Management \& Computer Applications, 7(3).

2. Akerlof, G. A. (1970). The Market for "Lemons": Quality Uncertainty and the Market Mechanism. The Quarterly Journal of Economics, 84(3), 488. https://doi.org/10.2307/1879431

3. Bebeji, A., Dogarawa, A. B., \& Sabari, M. (2014). Impact of Loan Loss Provisioning On Banks Credits in Nigeria during Consolidation Period. International Journal of Business and Management Invention, 3(11).

4. Bwacha, C. R. \& Xi, J. (2018). The Impact of Liquidity An explanatory study of the banking.

5. Central bank of Kenya (2013). Prudential guideline.

6. Chantal, M., Namusonge, G. S., \& Shukla, J. (2018). Influence of Information Asymmetry on Commercial Banks Lending Performance in Rwanda. International Journal of Academic Research in Business and Social Sciences, 8(3). https://doi.org/10.6007/ijarbss/v8-i3/3912

7. Chary, L. \& Mohanty, R. (2009). Understanding value creation: the shareholder value perspective. LBS Journal of Management and Research, 7(1-2), 12-26.

8. Daoud, J. I. (2018). Multicollinearity and Regression Analysis. Journal of Physics: Conference Series, 949(1). https://doi.org/10.1088/1742-6596/949/1/012009

9. Donnellan, J. T. (2016). Agency Theory in Banking - ' Lessons from the 2007-2010 Financial Crisis .' International Journal of Business and Applied Social Science, 2(3), 38-49.

10. Feyzi, A., Ghorbanian, M., \& Berangi, V. (2016). Forecasting Credit 
Risk in Banks Listed on Tehran Stock Exchange. International Journal of Finance and Managerial Accounting, 1(3), 3.

11. Funso, K. T., Kolade, A. R., \& Ojo, O. M. (2012). Credit Risk and Commercial Banks' Performance in Nigeria: A Panel Model Approach. Australian Journal of Business and Management Research, 2(2), 31-38.

12. Gathaiya, R. N. (2017). Analysis of Issues Affecting Collapsed Banks.

13. Gujarati, D. N. (2013). Basic Econometrics 5ed. In The McGraw-Hill Companies.

14. Isaac, M., Willy, M., \& Anthony, W. (2017). The Influence of Credit Risk on Stock Returns. International Journal of Scientific and Research Publications, 7(5), 575-584.

15. Isanzu, S. J. (2017). The Impact of Credit Risk on the Financial Performance of Chinese Banks. Journal of International Business Research and Marketing, 2(3), 14-17. https://doi.org/10.18775/jibrm.1849-8558.2015.23.3002

16. Jensen, M. C. \& Meckling, W. H. (1976). Theory of Firms: Managerial Behaviour, Agency Costs and Ownership Structure. Journal of Financial Economics, 3(4), 305-360. https://doi.org/http://dx.doi.org/10.1016/0304-405X(76)90026-X

17. Luqman, O. S. (2014). The Effect of Credit Risk on the Performance of Commercial Banks in Nigeria. SSRN Electronic Journal. https://doi.org/10.2139/ssrn.2536531

18. Million, G., Matewos, K., \& Sujata, S. (2016). The impact of credit risk on profitability performance of commercial banks in Ethiopia. African Journal of Business Management, 9(2), 59-66. https://doi.org/10.5897/ajbm2013.7171

19. Muriithi, J. G., Munyua, W. K., \& Muturi, W. M. (2016). Effect of Credit Risk on Financial Performance of Commercial Banks Kenya. IOSR Journal of Economics and Finance, 07(04), 72-83. https://doi.org/10.9790/5933-0704017283

20. Nyoni, T. (2018). Information Asymmetry in the Banking Sector: A Zimbabwean Scenario. International Journal of Marketing \& Financial Management, 6(1), 45-51.

21. Palia, D., Porter, R., \& Palia, D. (2018). “ Agency Theory in Banking: An Empirical Analysis of Moral Hazard and the Agency Costs of Equity " Agency Theory in Banking : An Empirical Analysis of Moral Hazard. Banks and Bank Systems, 2(3).

22. Perera, L. A. S. \& Morawakage, P. S. (2017). Credit risk management and shareholder value creation: with special reference to listed commercial banks in Sri Lanka. Kelaniya Journal of Management, 5(2), 1. https://doi.org/10.4038/kjm.v5i2.7514 
23. Rasika, D. \& Sampath, H. (2016). Impact of Credit Risk on Financial Performance of Sri Lankan Commercial Banks. Sri Lanka Journal of Social Sciences, 1(42), 53-64.

24. Spence, M. (2006). Job Market Signaling. The Quarterly Journal of Economics, 87(3), 355. https://doi.org/10.2307/1882010

25. Stovrag, A. (2017). Capital Requirements and Bank Profitability. (January).

26. The Basel Committee (2006). Principles for the Management of Credit Risk. IFAS Extension, 1-33. Retrieved from http://edis.ifas.ufl.edu/pdffiles/HR/HR02200.pdf

27. The Basel Committee (2016). Basel III - what and why? Economic Review, 1, 16-93.

28. World bank (2019). Bank non performing loans to gross loans for Kenya. Retrieved from Federal Reserve Bank of St. Louis website: https://fred.stlouisfed.org/series/DDSI02KEA156NWDB

29. Zhao, S., Moreira, F., Wang, T., \& Wang, T. (2018). The Relationship among Sovereign Ratings, Bank Ratings and Bank Performances, Evidence from European Commercial Banks The Relationship among Sovereign Ratings, Bank Ratings and Bank Performances : Evidence from European commercial banks. 